\title{
Very Late Evaluation of the Use of Drug-Eluting Stents for the Treatment of Patients with Saphenous Vein Graft Lesions: One-Decade Experience of the DESIRE Registry
}

\author{
Bruno Palmieri Bernardi ${ }^{1}$, Amanda G. M. R. Sousa ${ }^{2}$, J. Ribamar Costa Junior ${ }^{3}$, Adriana Moreira ${ }^{4}$, \\ Ricardo A. da Costa ${ }^{5}$, Manuel Cano ${ }^{6}$, Galo Maldonado ${ }^{7}$, Cantídio Campos Neto ${ }^{8}$, Enilton Egito ${ }^{9}$, \\ Edson Romano ${ }^{10}$, Ricardo Pavanello ${ }^{11}$, J. Eduardo Sousa ${ }^{12}$
}

\begin{abstract}
Background: Percutaneous coronary intervention (PCI) in saphenous vein grafts remains a challenge for interventional cardiology, due to acute complications and the lack of data on the late efficacy of drug-eluting stents (DESs). Methods: Between May 2002 and January 2013, patients undergoing PCI with DES at Hospital do Coração were included in the DESIRE Registry. We evaluated the results of patients undergoing $\mathrm{PCI}$ in saphenous vein grafts (group 1), who were compared to those undergoing $\mathrm{PCl}$ in native vessels (group 2.) Results: Of a total of 4,655 patients, 311 were included in group 1 and 4,344 in group 2. Group 1 included older patients $(68.4 \pm 9.7$ years vs. $64 \pm 11.2$ years; $\mathrm{P}<0.01)$, more frequently male $(87.1 \%$ vs. $76.7 \% ; \mathrm{P}<0.01)$ with a higher incidence of comorbidities. Unstable angina was the most frequent clinical presentation in this group. Group 1 patients received large caliber stents $(3.18 \pm 1.11 \mathrm{~mm}$ vs. $2.86 \pm 0.43 \mathrm{~mm} ; \mathrm{P}<0.01)$ and were less frequently submitted to pre-dilation $(36.3 \%$ vs. $50.7 \%$; $\mathrm{P}$ $<0.01)$ and post-dilation (38.3\% vs. $58.4 \%$; $\mathrm{P}<0.01)$. They had a higher incidence of non-fatal acute myocardial infarction during hospitalization $(11.3 \%$ vs. $4.1 \% ; \mathrm{P}<0.01)$ and late major adverse cardiovascular events $(32.8 \%$ vs. $13.9 \%$; $\mathrm{P}<0.01)$, at the expense of cardiac death $(7.7 \%$ vs. $3.2 \%$; $P=0.02)$ and target-lesion revascularization $(9 \%$ vs. $4.3 \%$; $\mathrm{P}<0.01)$. Definitive stent thrombosis was more frequent in group $1(3.5 \%$ vs. $1 \%$; $\mathrm{P}<0.01)$. Conclusions: Despite the unquestionable benefit of DESs in the late outcomes of $\mathrm{PCl}$
\end{abstract}

RESUMO

Avaliação Muito Tardia do Uso de Stents
Farmacológicos para Tratamento de Pacientes com
Lesões em Enxertos de Veia Safena: Experiência de
uma Década do Registro DESIRE

Introdução: A intervenção coronária percutânea (ICP) em pontes de safena ainda representa um desafio à Cardiologia intervencionista, pelas complicações agudas e pela escassez de dados referentes à efetividade tardia dos stents farmacológicos (SFs). Métodos: Entre maio de 2002 e janeiro de 2013, pacientes submetidos à ICP com SF no Hospital do Coração foram incluídos no Registro DESIRE. Avaliamos os resultados de pacientes submetidos à ICP em pontes de safena (grupo 1), que foram comparados aos submetidos a ICP em vasos nativos (grupo 2). Resultados: De um total de 4.655 pacientes, 311 foram incluídos no grupo 1 e 4.344, no grupo 2 . O grupo 1 contou com pacientes mais idosos $(68,4 \pm 9,7$ anos vs. 64 $\pm 11,2$ anos; $P<0,01)$, com mais pacientes do sexo masculino $(87,1 \%$ vs. $76,7 \%$; $P<0,01)$ e com maior incidência de comorbidades. Angina instável foi a apresentação clínica mais frequente nesse grupo. Pacientes do grupo 1 receberam stents de maior calibre $(3,18 \pm 1,11 \mathrm{~mm}$ vs. $2,86 \pm 0,43$ $\mathrm{mm} ; \mathrm{P}<0,01)$ e foram submetidos menos frequentemente a pré-dilatação $(36,3 \%$ vs. 50,7\%; P $<0,01)$ e a pós-dilatação (38,3\% vs. 58,4\%; P<0,01). Apresentaram mais infarto agudo do miocárdio não-fatal na fase hospitalar $(11,3 \%$ vs. $4,1 \%$;

\footnotetext{
1 Interventionist cardiologist physician at Hospital do Coração da Associação do Sanatório Sírio. São Paulo, SP, Brazil.

2 Full professor. Cardiologist physician at Hospital do Coração da Associação do Sanatório Sírio. São Paulo, SP, Brazil.

${ }^{3}$ Doctor. Interventionist cardiologist physician at Hospital do Coração da Associação do Sanatório Sírio. São Paulo, SP, Brazil.

${ }^{4}$ Interventionist cardiologist physician at Hospital do Coração da Associação do Sanatório Sírio. São Paulo, SP, Brazil.

${ }^{5}$ Doctor. Interventionist cardiologist physician at Coração da Associação do Sanatório Sírio. São Paulo, SP, Brazil.

${ }^{6}$ Doctor. Interventionist cardiologist physician at Hospital do Coração da Associação do Sanatório Sírio. São Paulo, SP, Brazil.

7 Interventionist cardiologist physician at Hospital do Coração da Associação do Sanatório Sírio. São Paulo, SP, Brazil.

8 Programmer engineer at Hospital do Coração da Associação do Sanatório Sírio. São Paulo, SP, Brazil.
}

\begin{abstract}
${ }^{9}$ Cardiologist physician at Coração da Associação do Sanatório Sírio. São Paulo, SP, Brazil.

${ }^{10}$ Cardiologist physician at Hospital do Coração da Associação do Sanatório Sírio. São Paulo, SP, Brazil.

${ }^{11}$ Doctor. Cardiologist physician at Coração da Associação do Sanatório Sírio. São Paulo, SP, Brazil.

${ }^{12}$ Full professor. Head of the Invasive Cardiology Service of Hospital do Coração da Associação do Sanatório Sírio. São Paulo, SP, Brazil.
\end{abstract}

Correspondence to: J. Eduardo Sousa. Rua Desembargador Eliseu GuiIherme, 147 - Vila Mariana - São Paulo, SP, Brazil - CEP 04004-030 E-mail: jesousa@uol.com.br

Received on: 03/05/2013 • Accepted on: 05/21/2013 
in complex patients, the treatment of patients with saphenous vein graft lesions remains a challenge, with less favorable acute and late results than in patients with native vessel lesions.

DESCRIPTORS: Angioplasty. Drug-eluting stents. Saphenous vein. Coronary artery bypass. Coronary restenosis.

$\mathrm{T}$ he treatment of lesions in saphenous vein grafts persists as a challenge in the current phase of interventional cardiology, given the higher rate of acute complications and poor clinical outcome in the long term. Although drug-eluting stents (DES) have reduced restenosis rates in virtually all clinical and angiographic scenarios, improving the outcomes of percutaneous coronary intervention $(\mathrm{PCl})$, there are still doubts regarding the late efficacy and safety of these new devices when used in treatment of lesions in saphenous vein bypass grafts.

This study presents the in-hospital and very late clinical results of a consecutive, unselected cohort of patients with lesions in saphenous vein grafts treated exclusively with DES.

\section{METHODS}

\section{Study Population}

Since May of 2002, upon approval the first DES for clinical use in Brazil, the Drug Eluting Stents In the Real World (DESIRE) registry was started at Hospital do Coração da Associação do Sanatório Sírio (HCor - São Paulo, SP), consecutive and prospectively including all patients treated with at least one DES.

The present analysis included patients registered in the Hospital's database until January 2013, and excluded patients who received DES and bare-metal stents (BMS) at the same procedure. Virtually all clinical scenarios are represented in this analysis, except primary rescue and PCls, as the authors considered that the concomitant inclusion of venous grafts and myocardial infarction with ST-segment elevation segment could represent a significant bias in result interpretation, since it is known that both scenarios are associated with worse outcomes after PCl. Patients whose target lesion was a segment with restenosis of a previously implanted stent (whether DES or not) were also excluded.

The remaining patients were then divided into two groups for comparison: group 1, patients with lesions in saphenous vein grafts, and group 2, patients with lesions in native coronary arteries.
$\mathrm{P}<0,01)$ e mais eventos cardiovasculares adversos maiores na fase tardia $(32,8 \%$ vs. $13,9 \%$; $P<0,01)$, à custa de óbito cardíaco $(7,7 \%$ vs. 3,2\%; $\mathrm{P}=0,02)$ e de revascularização da lesão-alvo ( $9 \%$ vs. 4,3\%; $\mathrm{P}<0,01)$. Trombose definitiva do stent foi mais frequente no grupo $1(3,5 \%$ vs. $1 \%$; $\mathrm{P}<0,01)$.

DESCRITORES: Angioplastia. Stents farmacológicos. Veia safena. Ponte de artéria coronária. Reestenose coronária.

\section{Adjunctive drug therapy}

For group 1 patients, often with lesions in degenerated venous grafts or significant thrombotic burden, the routine procedure at the present institution consists of a more intense antithrombotic pre-treatment, including dual antiplatelet therapy with acetylsalicylic acid (ASA, loading dose of $500 \mathrm{mg}$ and maintenance dose of $100 \mathrm{mg}$ a day), clopidogrel (loading dose of 300-600 $\mathrm{mg}$ and maintenance dose of $75 \mathrm{mg}$ a day), and low molecular weight heparin ( $1 \mathrm{mg} / \mathrm{kg}$ every 12 hours), whenever possible, for five to seven days before PCI. After the procedure, ASA is maintained indefinitely and clopidogrel for at least 12 months. The control group (group 2) received routine pre-treatment (ASA loading dose of $500 \mathrm{mg}$ and clopidogrel loading dose of 300-600 mg) for 24 hours before the procedure.

The use of other drugs, such as glycoprotein IIb/IIla inhibitors and adjunct devices, such as distal protection filters, and the type of DES to be implanted were at the discretion of each surgeon.

\section{Study definitions}

Technical success was considered when a residual lesion $<20 \%$ was attained without the presence of thrombi, changes in coronary flow, or dissections at the implanted prosthesis edges.

Deaths were classified as cardiac and non-cardiac. Deaths of undetermined causes were considered cardiac. Myocardial infarctions were classified based on the electrocardiographic changes during evolution, increased enzyme concentration (creatine kinase $M B$ fraction $[C K-M B]>$ two-fold normal levels) or both findings.

All reoperations resulting from lesion recurrence within the stent implanted in the index procedure or vascular segment, which included the $5 \mathrm{~mm}$ proximal and $5 \mathrm{~mm}$ distal to the stent, were classified as target lesion revascularization (TLR). As this is a real-world registry, all restenoses were associated with symptom recurrence and/or positive functional tests. Other repeated procedures in the same vessel, but outside the described segment were classified as revascularization of non-target lesion. 
Stent thrombosis was classified according to the definition proposed by the Academic Research Consortium: definite (angiographic or anatomopathological confirmation), probable (sudden death 30 days after $\mathrm{PCl}$ or infarction related to the treated artery region, even without angiographic confirmation), and possible (sudden death $>30$ days post-PCI). As for the temporal classification, prosthetic thromboses were divided into acute and sub-acute (up to 30 days), late (31 to 360 days), and very late (> 360 days).

During hospitalization, all patients were submitted to electrocardiographic and biochemical markers evaluation (CK-MB and troponin), at three different moments: before and after the intervention, and, when necessary, at hospital discharge.

A dedicated database was developed, which contained detailed data on clinical and angiographic characteristics and technical information on the intervention of each of the registered patients. The hospital evolution data and those obtained in the late phase (one month, six months, 12 months, and annually thereafter) after the index procedure were also recorded.

\section{Statistical analysis}

Continuous variables are shown as means and standard deviations. Categorical variables are shown as numbers and percentages. Student's t-test was used to compare means and the chi-squared test was used to compare proportions. P-values $<0.05$ were considered statistically significant.

\section{RESULTS}

From May of 2002 to January of 2013, of a total of 4,665 patients from the DESIRE registry that met the criteria of this study, 311 had lesions treated in saphenous vein grafts (group 1) and 4,344 had lesions treated in native vessels (group 2).

Regarding clinical characteristics (Table 1), patients in group 1 were more often males $(87.1 \%$ vs. $76.7 \%$; $\mathrm{P}<0.01)$, older $(68.4 \pm 9.7$ years vs. $64 \pm 11.2$ years; $\mathrm{P}<0.01$ ), and had greater incidence of comorbidities, especially chronic renal failure $(17 \%$ vs. $8.2 \%$; $\mathrm{P}<0.01)$. The incidence of diabetes mellitus, however, did not differ between the groups $(34.1 \%$ vs. $30.3 \%$; $P=0.16)$. The most common initial clinical presentation in group 1 was coronary syndrome without ST-segment elevation (44.4\% vs. $36.9 \%)$. The mean age of venous grafts was $11.3 \pm 5.3$ years.

Regarding the angiographic and procedural characteristics (Table 2), patients in group 1 had greater reference diameter of the treated vessel $(3.03 \pm 0.68$ $\mathrm{mm}$ vs. $2.72 \pm 0.65 \mathrm{~mm} ; \mathrm{P}<0.01)$, with equal lesion

TABLE 1

Baseline clinical characteristics

\begin{tabular}{|c|c|c|c|}
\hline & $\begin{array}{l}\text { Group } 1 \\
(\mathrm{n}=311 \\
\text { patients) }\end{array}$ & $\begin{array}{c}\text { Group } 2 \\
\text { (n=4,344 } \\
\text { patients) }\end{array}$ & $\mathbf{P}$ \\
\hline Age, years & $68.4 \pm 97$ & $64 \pm 11.2$ & $<0.01$ \\
\hline Male gender, n (\%) & $271(87.1)$ & $3,333(76.7)$ & $<0.01$ \\
\hline Arterial hypertension, $\mathrm{n}(\%)$ & $262(84.2)$ & $3,308(76.2)$ & $<0.01$ \\
\hline Dyslipidaemia, n (\%) & $223(71.7)$ & $2,695(62)$ & $<0.01$ \\
\hline Diabetes mellitus, n (\%) & $106(34.1)$ & $1,316(30.3)$ & 0.16 \\
\hline Smoking, n (\%) & $75(24.1)$ & $1,333(30.7)$ & 0.015 \\
\hline Obesity, n (\%) & $82(26.4)$ & $1,168(26.9)$ & 0.89 \\
\hline Renal failure, n (\%) & $53(17)$ & $355(8.2)$ & $<0.01$ \\
\hline Family history of coronary artery disease, n (\%) & $104(33.4)$ & $1,575(36.3)$ & 0.33 \\
\hline Previous acute myocardial infarction, n (\%) & $106(34.1)$ & $957(22)$ & $<0.01$ \\
\hline Previous percutaneous coronary intervention, n (\%) & $83(26.7)$ & $1,059(24.4)$ & 0.38 \\
\hline Clinical presentation, $\mathrm{n} \%$ & & & $<0.01$ \\
\hline Stable angina/silent ischaemia & $170(54.7)$ & $2,570(59.2)$ & \\
\hline Acute coronary syndrome without ST-segment elevation & $138(44.4)$ & $1,603(36.9)$ & \\
\hline Acute coronary syndrome with ST-segment elevation (> 72 hours) & $3(0.9)$ & $171(3.9)$ & \\
\hline
\end{tabular}


TABLE 2

Baseline angiographic and procedural characteristics

\begin{tabular}{|c|c|c|c|}
\hline & $\begin{array}{c}\text { Group } 1 \\
(\mathrm{n}=553 \text { lesions })\end{array}$ & $\begin{array}{c}\text { Group } 2 \\
(\mathrm{n}=\mathbf{6 , 7 3 5} \text { lesions })\end{array}$ & $\mathbf{P}$ \\
\hline Treated vessel, $\mathrm{n} \%$ & & & NA \\
\hline Saphenous vein graft to the left anterior descending artery & $77(13.9)$ & - & \\
\hline Saphenous vein graft to the diagonal & $106(19.2)$ & - & \\
\hline Saphenous vein graft to the marginal & $205(37.1)$ & - & \\
\hline Saphenous vein graft to the right coronary & $165(29.8)$ & - & \\
\hline Right coronary artery & - & $1,908(28.3)$ & \\
\hline Left anterior descending artery & - & $2,933(43.50$ & \\
\hline Left circumflex artery & - & $1,812(26.9)$ & \\
\hline Left main coronary artery & - & $82(1.3)$ & \\
\hline Reference diameter & $3.03 \pm 0.68$ & $2.72 \pm 0.65$ & $<0.01$ \\
\hline Lesion length & $17 \pm 8.2$ & $17.6 \pm 8.7$ & 0.12 \\
\hline Calcification, n (\%) & & & $<0.01$ \\
\hline Mild & $456(82.4)$ & $5,042(75)$ & \\
\hline Moderate & $93(17)$ & $1,546(23)$ & \\
\hline Severe & $4(0.72)$ & $147(2.18)$ & \\
\hline Presence of thrombus, n (\%) & $50(9)$ & $173(2.6)$ & $<0.01$ \\
\hline Pre-dilatation, n (\%) & $201(36.3)$ & $3,418(50.7)$ & $<0.01$ \\
\hline Post-dilatation, n (\%) & $212(38.3)$ & $3,936(58.4)$ & $<0.01$ \\
\hline Stent diameter, $\mathrm{mm}$ & $3.18 \pm 1.11$ & $2.86 \pm 0.43$ & $<0.01$ \\
\hline Stent length, $\mathrm{mm}$ & $19.9 \pm 6$ & $20.1 \pm 6.4$ & 0.48 \\
\hline Distal filter protection, n (\%) & $23(4.1)$ & 0 & $<0.01$ \\
\hline
\end{tabular}

extension $(17 \pm 8.2 \mathrm{~mm}$ vs. $17.6 \pm 8.7 \mathrm{~mm} ; \mathrm{P}=0.12)$. The presence of thrombus was more frequent in this group (9\% vs. $2.6 \%$; $\mathrm{P}<0.01)$.

Pre-dilation (36.3\% vs. 50.7\%; $\mathrm{P}<0.01)$ and postdilation procedures $(38.3 \%$ vs. $58.4 \%$; $\mathrm{P}<0.01)$ were less frequent in the treatment of lesions in saphenous vein grafts. Distal protection filters were used in $4.1 \%$ of patients in group 1.

Clinical follow-up was attained in $97 \%$ of patients (median follow-up of 4.7 years). Patients with lesions in saphenous vein grafts had more non-fatal acute myocardial infarction during hospitalization $(11.3 \%$ vs. $4.1 \%$; $\mathrm{P}<0.01)$, but there were no differences in death $(0.3 \%$ vs. $0.2 \% ; P=0.60)$ or emergency targetlesion revascularization rates (0\% vs. $0.02 \%$; $\mathrm{P}>0.99)$. At the late phase, these patients presented a higher incidence of major adverse cardiac events $(32.8 \% \mathrm{vs}$. $13.9 \% ; \mathrm{P}<0.01)$, cardiac mortality $(7.7 \%$ vs. $3.2 \%$; $\mathrm{P}=0.02)$, and repeat revascularization of the targetlesion ( $9 \%$ vs. $4.3 \%$; $\mathrm{P}<0.01)$ (Table 3$)$. The incidence of definite thrombosis was also more frequent in this group $(3.5 \%$ vs. $1 \%$; $\mathrm{P}<0.01)$ (Table 4$)$.

\section{DISCUSSION}

The main findings of the present study were: 1) compared to $\mathrm{PCl}$ in native vessels, the percutaneous approach of saphenous grafts, even with DES, had a more adverse evolution, from the in-hospital phase until a later phase; 2) the main adverse event related to the percutaneous approach of saphenous grafts was the occurrence of periprocedural infarction, probably related to the embolization of debris.

Patients with obstructive disease in saphenous grafts are usually older, present more comorbidities, and greater risk of adverse events when submitted to a new coronary artery bypass graft (CABG) surgery. ${ }^{1}$ Thus, $\mathrm{PCl}$ in saphenous grafts became the preferred method of treatment for these patients, accounting for $5 \%$ to $10 \%$ of all PCls performed in clinical practice. $^{2}$ 
TABLE 3

Incidence of major adverse cardiac events

\begin{tabular}{|c|c|c|c|}
\hline & $\begin{array}{c}\text { Group } 1 \\
(\mathrm{n}=311 \text { pacients })\end{array}$ & $\begin{array}{c}\text { Group } 2 \\
(n=4,344 \text { pacients })\end{array}$ & $\mathbf{P}$ \\
\hline \multicolumn{4}{|l|}{ Hospital phase, n (\%) } \\
\hline Cardiac death & $1(0.3)$ & $9(0.2)$ & 0.60 \\
\hline Non-fatal acute myocardial infarction & $35(11.3)$ & $179(4.1)$ & $<0.01$ \\
\hline Emergency target-lesion revascularisation & 0 & $1(0.02)$ & $>0.99$ \\
\hline \multicolumn{4}{|l|}{ Late phase, n (\%) } \\
\hline Cardiac death & $24(7.7)$ & $138(3.2)$ & 0.02 \\
\hline Non-fatal acute myocardial infarction & $14(4.5)$ & $89(2)$ & 0.08 \\
\hline Target-lesion revascularisation & $28(9)$ & $187(4.3)$ & 0.08 \\
\hline Cumulative major adverse cardiac event, $(\%)$ & $102(32.8)$ & $603(13.9)$ & $<0.01$ \\
\hline
\end{tabular}

TABLE 4

Incidence of stent thrombosis

\begin{tabular}{|c|c|c|c|}
\hline & $\begin{array}{c}\text { Group } 1 \\
(\mathrm{n}=311 \text { pacients })\end{array}$ & $\begin{array}{c}\text { Group } 2 \\
(n=4,344 \text { pacients })\end{array}$ & $\mathbf{P}$ \\
\hline Definite, n (\%) & $11(3.5)$ & $44(1)$ & $<0.01$ \\
\hline Probable, n (\%) & 0 & $2(0.05)$ & $>0.99$ \\
\hline Possible, n (\%) & $4(1.3)$ & $41(0.94)$ & 0.54 \\
\hline Total, n (\%) & $15(4.8)$ & $87(2)$ & $<0.01$ \\
\hline
\end{tabular}

Although initial observational and retrospective studies have reported the superiority of DES over BMS in decreasing adverse events (mainly restenosis and new revascularisations) in venous grafts interventions, ${ }^{3,4}$ data from randomized trials have shown discrepant results. The randomized trial Reduction of Restenosis In Saphenous vein grafts with Cypher sirolimus-eluting stent (RRISC), which included 75 patients, presented lower late luminal loss and lower restenosis and new revascularizations rates at six months with sirolimuseluting stents (SES) when compared with BMS. ${ }^{5}$ However, although without statistical power to evaluate clinical outcomes, the post-hoc analysis of that study with three years of follow-up reported similar rates of target-vessel revascularization between SES and BMS, in addition to a significantly higher rate of mortality from all causes with SES, which raised questions regarding the long-term safety of using DES in the treatment of degenerated venous grafts.

The findings of that study were not replicated in subsequent series, including the largest randomized trial specific for this scenario, Is drug-eluting Stenting Associated with Improved Results in Coronary Artery
Bypass Grafts" (ISAR - CABG), which randomized 610 patients for the treatment of degenerated venous grafts with DES or BMS. The occurrence of combined primary outcome at 12 months (death, infarction, or target-lesion revascularization guided by ischemia) was significantly lower in patients treated with DES (15\% vs. 22\%; P = 0.03) than in those treated with BMS. There were no significant differences between groups regarding the occurrence of death, infarction, or stent thrombosis, with a difference in primary outcome reflecting a relative risk reduction of approximately $50 \%$ of new revascularization with the use of DES. Angiographic study at six to eight months was performed in $72 \%$ of patients, which demonstrated that the DES had significantly lower rates of binary restenosis (15\% vs. 29\%; P < 0.0001) and graft occlusion ( $6 \%$ vs. $12 \% ; P=0.02) .{ }^{6}$ Although at a first glance the adverse event rates in the DESIRE registry appear to be relatively high, it is important to note that the literature does not offer very late follow-up ( $>$ three years) data for patients treated with DES in saphenous vein grafts; therefore, it becomes difficult to compare the present experience with the international context. However, is always important to recall the natural history of venous grafts, in which the progression of 
atherosclerotic disease occurs more rapidly. At the end of five years, approximately $20 \%$ to $35 \%$ of the grafts are occluded, while at the end of a decade, $50 \%$ are occluded and approximately half of patent grafts are already degenerated. ${ }^{7}$

In such a difficult context, $32.7 \%$ MACE in up to ten years of follow-up (median 4.7 years) appears to be favourable, although the authors believe that this is one of fields in which interventional cardiology needs to progress, as the current results are still quite below those obtained with native vessels.

\section{CONCLUSIONS}

Despite the unquestionable benefits of DES on the late outcomes of $\mathrm{PCl}$ in complex patients, the percutaneous treatment of patients with saphenous vein graft lesions remains a challenge to interventional cardiology, with less favorable acute and late outcomes than those in native vessels. However, is worth mentioning that, to date, these tools still remain the best option for the percutaneous treatment of venous graft lesions.

\section{CONFLICTS OF INTEREST}

The authors declare no conflicts of interest.

\section{REFERENCES}

1. Loop FD, Lytle BW, Cosgrove DM, Woods EL, Stewart RW, Golding LA, et al. Reoperation for coronary atherosclerosis. Changing practice in 2509 consecutive patients. Ann Surg.1990;212(3):378-85.

2. Lee MS, Park SJ, Kandzari DE, Kirtane AJ, Fearon WF, BrilakisES, et al. Saphenous vein graft intervention. JACC Cardiovasc Interv. 2011; 4(8): 831-43.

3. Ge L, lakovou I, Sangiorgi GM, Chieffo A, Melzi G, Cosgrave J, et al. Treatment of saphenous vein graft lesions with drugeluting stents: immediate and midterm outcome. J Am Coll Cardiol. 2005; 45(7): 989-94.

4. Lee MS, Shah AP, Aragon J, Jamali A, Dohad S, Kar S, et al. Drug-eluting stenting is superior to bare metal stenting in saphenous vein grafts. Catheter Cardiovasc Interv. 2005; 66(4): 507-11.

5. Vermeersch $\mathrm{P}$, Agostoni $\mathrm{P}$, Verheye S, Van den Heuvel $\mathrm{P}$, Convens C, Bruining $N$, et al. Randomized double-blind comparison of sirolimus-eluting stent versus bare-metal stent implantation in diseased saphenous vein grafts: six-month angiographic, intravascular ultrasound, and clinical follow-up of the RRISC Trial. J Am Coll Cardiol. 2006;48(12):2423-31.

6. Mehilli J, Pache J, Abdel-Wahab M, Schulz S, Byrne RA, Tiroch $\mathrm{K}$, et al. Drug-eluting versus bare-metal stents in saphenous vein graft lesions (ISAR-CABG): a randomised controlled superiority trial. Lancet. 2011; 378(9796): 1071-8.

7. Fitzgibbon GM, Kafka HP, Leach AJ, Keon WJ, Hooper GD, Burton JR. Coronary bypass graft fate and patient outcome: angiographic follow-up of 5,065 grafts related to survival and reoperation in 1,388 patients during 25 years. J Am Coll Cardiol. 1996; 28(3): 616-26. 